Ciorum appeared to have been the most affected during the preceding month, though Balikesir was also damaged. During this time about 20 people were killed, 24 injured, 1,600 houses totally wrecked and some further 1,300 partly wrecked.

The most recent very strong earthquake took place on December 21, 1942, and the epicentre appears to have been slightly to the east and very close to Erba. This place is approximately a hundred miles to the east of Ciorum, and west-north-west of the epicentre of the very severe 1939 (Erzinjan) earthquake. On the recent occasion Erba was almost completely destroyed, partly by the earthquake and partly by the fires which followed it, and it is feared that more than a thousand people have perished. Niksar, east of Erba, also suffered severely, as did the intervening villages. Erba is the centre of a rich tobacco-growing region about eighty miles south-east of Samsun on the Turkish Black Sea coast, and about 280 miles east of Istanbul. The strong shocks were also felt severely in Ordu, Sivas, Kastamuni, Bakir-chai, Tokat, Fatza, Kaisarieh and Zara, though no major damage is reported from the last-named place.

\section{North African Natural History}

As suggested earlier in the War, the armies in North Africa have stimulated much useful war-time observation of fauna and flora in otherwise difficult regions, and, the current issue of Countryside (12, No. 5) contains original papers by members serving abroad. These include notes on the birds of the British list wintering in West Africa by A. C. Allnutt, who noticed that while whinchats wintered in the coastal region for the whole of the six winter months, the willow-warblers arrived in waves of migration and remained only a few days. Blue-headed and grey-headed wagtails were there from December until February but no nuptial songs were heard. Their feeding habits were no different from those observed in Europe. Waders seen regularly included the marsh-sandpiper, ringed plover, greenshank, bartailed godwit, black-winged stilt ; those seen mainly on passage were the sandpiper, curlew-sandpiper, grey plover, redshank, spotted redshank, little stint, turnstone and sanderling. Migrating sandwich terns remained for several weeks, and the arctic skua and black tern were noted. Previous numbers of this volume of Countryside have contained notes on the birds of Tobruk. In the current issue Col. W. R. Roberts has notes on the flora of the Egyptian wadis near Cairo.

\section{Fruit Growing}

Arlotments and gardens, though small units of horticultural production, are now so numerous that their aggregate contribution to the nation's nutrition is not small. The Ministry of Agriculture and Fisheries has recently" issued "Growmore" Bulletin No. 7, "Fruit from the Garden" (H.M. Stationery Office, 3d. net, 1942) to assist the small grower to increase his production of fruit. Mr. J.M. S. Potter, of the Royal Horticultural Society, has written the text, which deals adequately with the planting and general management of stone fruits, apples and soft fruits. The bulletin's advice is eminently suited to the southern parts of Britain, but northern growers should not be advised to "avoid the strong growers like Bramley's Seedling and Newton Wonder". These varieties are often the most suitable for difficult climates. Many small apple orchards in the north are also unpro- ductive because of the relative scarcity of other trees for pollination, and it is disappointing to find scant mention of suitable pollinating kinds for each variety. A useful spraying calendar is given, and sections on picking and storing, pruning, and the treatment of old trees also appear. Fruit culture is never so economically successful as when practised on a domestic scale, and it is good to see the Ministry's recognition of this important fact.

\section{Planning of Science : in War and in Peace}

THE Association of Scientific Workers is organizing a conference to be held on January 30 and 31 , at the Caxton Hall, London, S.W.1, on the planning of science in war and in peace. Sir Robert Watson-Watt, president of the Association, will open the Conference. The first session will deal with the central direction of scientific research and development, and Sir Stafford Cripps has agreed to speak. It is also hoped to have statements on the organization of science in the U.S.A. and the U.S.S.R. The second session will be devoted to the local organization of scientific research and its application; among the speakers will be $\mathrm{Mr}$. W. C. Devereux, managing director of High Duty Alloys, and Mr. Ben Smith, national organizer of the Association, who will speak on the relationship between managements and scientific staff as it affects production; detailed consideration will be given to the relations between scientific and other workers and to the work of joint production committees. The third session will discuss those changes in the organization of science brought about during the War which may have a continuing effect on the relations of science with society, and the re-orientation of science after the War. Prof. P. M. S. Blackett and Sir Lawrence Bragg will be the main speakers. The chair will be taken by Prof. J. D. Bernal. Tickets $(2 s .6 d$. for whole conference or $1 s$. per session at the door) and full particulars can be obtained from the Conference Secretary, Association of Scientific Workers, 73 High Holborn, London, W.C.1.

\section{Announcements}

No. 3 of the War Background Studies issued by the Smithsonian Institution is by Dr. Aleš Hrdlicka and is devoted to an account of the peoples of the Soviet Union. While there is nothing in these twentynine pages which purports to be new matter, the little publication gives a very convenient conspectus of the early history and make-up of the peoples of the U.S.S.R. It is compiled for the general public.

THE following appointments and promotions in the Colonial Service have recently been made: J. F. A. Sprent, veterinary research officer, Nigeria; I. H. Pattison, veterinary officer, Palestine; J. R. Curry (agricultural officer, Tanganyika Territory), director of agriculture, Bahamas; M. Greenwood (specialist (chemistry), Agricultural Department, Gold Coast), senior specialist, Agricultural Department, Gold Coast.

THE Institution of Naval Architects is offering two scholarships in naval architecture (Elgar Scholarship, $£ 130$ a year, and Denny Scholarship, £100 a year) and two in marine engineering (Parsons Scholarship, $£ 150$ a year, and Yarrow Scholarship, $£ 100$ a year) for competition in 1943. The age limit for the Denny Scholarship is nineteen, and that for the other scholarships twenty-three. Particulars can be obtained from the secretary of the Institution, 10 Upper Belgrave Street, London, S.W.I. 